\title{
PENINGKATAN KETERAMPILAN MENULIS TEKS CERITA SEJARAH SISWA KELAS XII IPS SMAN 1 GARUT MENGGUNAKAN MODEL DISCOVERY LEARNING MELALUI MEDIA FILM
}

\section{Yulianti | Ernawati | Has'ad Rahman Attamimi}

How to cite : Yulianti, Ernawati, \& Attamimi, Has'ad Rahman., 2021. PENINGKATAN KETERAMPILAN MENULIS TEKS CERITA SEJARAH SISWA KELAS XII IPS SMAN 1 GARUT MENGGUNAKAN MODEL DISCOVERY LEARNING MELALUI MEDIA FILM. Jurnal Penelitian dan Penilaian Pendidikan. 3(2). 146 - 161.

To link to this article : https://doi.org/10.22236/jppp.v3i1.6798

C2021. The Author(s). This open access article is distributed under a Creative Commons Attribution (CC BY-SA) 4.0 license.

Published Online on 30 July 2021

https://journal.uhamka.ac.id/index.php/jppp

View Crossmark data 


\title{
PENINGKATAN KETERAMPILAN MENULIS TEKS CERITA SEJARAH SISWA KELAS XII IPS SMAN 1 GARUT MENGGUNAKAN MODEL DISCOVERY LEARNING MELALUI MEDIA FILM
}

\author{
Yulianti $^{1}$, Has'ad Rahman Attamimi², Ernawati Ernawati ${ }^{3} \bowtie$ \\ ${ }^{1}$ SMA Negeri 1 Garut \\ ${ }^{2}$ STIKES Griya Husada Sumbawa \\ ${ }^{3}$ Universitas Muhammadiyah Prof DR HAMKA \\ E-mail: $\quad$ yyulianti322@gmail.com ${ }^{l)}$ \\ hasad.rahman@uhamka.ac.id ${ }^{2)}$ \\ ernawati@uhamka.ac.id $^{31}$
}

\begin{abstract}
Abstrak
Penelitian termasuk penelitian tindakan kelas (PTK) yang dilaksanakan dalam dua siklus dengan melalui empat tahapan yakni perencanaan, pelaksanaan tindakan, observasi, dan refleksi terhadap siswa kelas XII IPS 1 SMAN 1 Garut yang berjumlah 36 siswa.Pengumpulan data digunakan dengan teknik observasi dan tes. Analisis data dilakukan secara interaktif yaitu melalui tahapan reduksi data (data reduction), penyajian data (data display), dan penarikan kesimpulan/verifikasi data (conclusion drawing/verification). Penelitian dapat dikatakan berhasil apabila memenuhi indikator rata-rata nilai minimal 80 dengan ketuntasan 90\%. Hasil penelitian menunjukkan bahwa proses pembelajaran berlangsung dengan lancar, kendala-kendala yang muncul pada siklus 1 dan IIdapat diatasi dengan baik. Kedua, terjadi peningkatan rata-rata nilai dari 70,4 pada kondisi awal, meningkat menjadi 78,3 setelah tindakan siklus I, dan meningkat lagi menjadi 88,9 pada siklus II. Hal ini berarti terjadipeningkatan sebesar 18,5 poin. Selain itu, terjadi peningkatan jumlah siswa tuntas sebanyak $69,5 \%$ dari 8 siswa $(22,2 \%)$ pada kondisi awal, meningkat menjadi 24 siswa $(66,7 \%)$ setelah tindakan siklus I, dan meningkat lagi menjadi 33 siswa $(91,7 \%)$ pada siklus II..
\end{abstract}

Kata kunci: Discovery Learning, Media Film, Teks Cerita Sejarah.

\begin{abstract}
The research included classroom action research (PTK) which was carried out in two cycles through four stages, namely planning, implementing action, observing, and reflecting on class XII IPS 1 students of SMAN 1 Garut with a total of 36 students. Data collection is used by observation and test techniques. Data analysis was carried out interactively, namely through the stages of data reduction (data reduction), data presentation (data display), and drawing conclusions/data verification (conclusion drawing/verification). Research can be said to be successful if it fulfills the minimum average value indicator of 80 with $90 \%$ completeness. The results of the research show that the learning process runs smoothly, the obstacles that arise in cycles 1 and II can be overcome properly. Second, there was an increase in the average score from 70.4 in the initial conditions, increased to 78.3 after the first cycle of action, and increased again to 88.9 in the second cycle. This means an increase of 18.5 points. In addition, there was an increase in the number of students completing as much as $69.5 \%$ from 8 students $(22.2 \%)$ in the initial conditions, increasing to 24 students $(66.7 \%)$ after the first cycle action, and increasing again to 33 students $(91,7 \%)$ in cycle II..
\end{abstract}

Keywords: Discovery Learning, Film Media, Historical Story Text. 


\section{PENDAHULUAN}

Keterampilan menulis sebagai salah satu keterampilan berbahasa sangat penting dalam dunia pendidikan dari tingkat dasar hingga perguruan tinggi. Kegiatan menulis tidak pernah lepas dilakukan siswa dalam proses belajar-mengajar. Menurut Sutarno (2008:10) pada dasarnya menulis adalah suatu cara yang tepat untuk mewujudkan, menjabarkan, dan menuangkan ide, konsep, gagasan, dan pikiran ke dalam sebuah tulisan. Selanjutnya, Sutarno mengemukakan bahwa tulisan seseorang pada dasarnya merupakan rekaman atas penglihatan, pengamatan, pembelajaran, pengalaman, penghayatan, pemaknaan, dan pengolahan daya pikir seorang penulis.

Salah satu kompetensi dasar yang berhubungan dengan menulis yang terdapat pada kurikulum kelas XII semester 1 adalah memproduksi teks cerita sejarah. Namun, dalam proses pencapaian indikator pembelajaran memproduksi teks cerita sejarah secara tertulis sering terhambat dengan kemampuan siswa dalam menentukan ide cerita. Begitu pula yang terjadi di kelas XII IPS 1 SMAN 1 Garut. Langkah-langkah pembelajaran yang dilakukan sesuai dengan tuntunan buku paket adalah;

1) Siswa mendata peristiwa sejarahdari berbagai sumber;

2) Siswa memilih salah satu peristiwa sejarah yang paling menarik;

3) Siswa membuat bagian-bagian peristiwa faktual, sisi lain kehidupan tokoh, serta imajinasi ke dalam kerangka cerita;

4) Siswa membuat rangkaian peristiwa faktual, dan;

5) Siswa menyusun cerita sejarah berdasarkan daya khayal.

Dengan langkah-langkah pembelajaran seperti di atas, siswa kesulitan dalam mengembangkan ide cerita. Siswa terjebak dalam fakta-fakta sejarah yang telah mereka dapatkan sehingga teks cerita sejarah yang telah disusun kurang mengembangkan sisi imajinasinya. Hasil teks cerita sejarah yang telah disusun seperti tidak berbeda dengan teks sejarah. Selain itu, masih ada siswa yang kesulitan mengembangkan idenya sehingga hasil tulisannya tidak utuh dan kurang sistematis. Hal ini membuat hasil belajar siswa banyak yang tidak mencapai KKM.

Untuk dapat melaksanakan tugasnya secara profesional, seorang guru dituntut dapatmemahami dan memiliki keterampilan yang memadai dalam mengembangkan berbagai model pembelajaran yang efektif, kreatif, dan menyenangkan. Salah satu model pembelajaran yang bisa digunakan dalam pembelajaran menulis teks cerita sejarah yaitu model pembelajaran discovery learning. Model pembelajaran discovery learning menurut Hanafiah (2012: 77) adalah suatu rangkaian pembelajaran yang melibatkan secara maksimal seluruh kemampuan peserta didik untuk mencari dan menyelidiki secara sistematis, kritis, dan logis sehingga mereka dapat menemukan sendiri pengetahuan, sikap, dan keterampilan sebagai wujud adanya perubahan perilaku. Guru sebagai fasilitator yang bertugas mengarahkan siswa bukan mendikte siswa. Seperti yang dikemukakan oleh Syah (2014: 243) bahwa peran guru hanya menyajikan pelajaran sebagian saja, selebihnya diberikan kepada siswa untuk menemukan dan mencari sendiri. Adapun langkah-langkah model pembelajaran discovery learning menurut Mulyasa \& Dadang Iskandar (2016:128) adalah 1) pemberian rangsangan (stimulation), 2)identifikasi masalah (problem identification), 3) pengumpulan data (data collection), 4) pemrosesan data (data processing), 5) pembuktian (verification), dan 6) menarik kesimpulan (generalization). 
Model pembelajaran discovery learning akan lebih menarik bagi siswa dengan menggunakan media audiovisual. Media audiovisual secara teori mampu menarik perhatian siswa. Pada era sekarang siswa sangat antusias dengan pembelajaran berbasis teknologi. Siswa sudah begitu erat dengan berbagai teknologi, jadi sangat relevan jika memakai media audiovisual dalam proses pembelajaran. Dalam menulis teks cerita sejarah, media audiovisual sangat mendukung untuk diterapkan. Salah satunya adalah film.

Sumarno (1996:28) menyatakan bahwa sebagai karya seni, film terbukti mempunyai kemampuan kreatif. Media film mempunyai kesanggupan untuk menciptakan suatu realitas rekaan sebagai bandingan terhadap realitas. Realitas imajiner itu dapat menawarkan rasa keindahan, renungan, atau sekadar hiburan. Dalam tampilannya, film sudah memiliki tema dan alur cerita yang cukup jelas karena dalam pembuatan sebuah film, semua skenario sudah dipersiapkan dengan matang. Selain sebagai karya seni, film disebut juga gambar hidup (motion pictures), yaitu serangkaian gambar diam (still pictures) yang meluncur secara cepat dan diproyeksikan sehingga menimbulkan kesan hidup dan bergerak. Film merupakan media yang menyajikan pesan audio visual dan gerak. Oleh karena itu, film memberikan kesan yang impresif bagi pemirsanya. Selain itu, film juga dapat diartikan sebagai gambar-gambar dalam frame yang mana frame demi frame diproyeksikan melalui lensa proyektor secara mekanis sehingga pada layar terlihat gambar itu hidup.

\section{METODE PENELITIAN}

\section{Jenis Penelitian}

Jenis penelitian yang digunakan adalah Penelitian Tindakan Kelas (PTK). Menurut Arikunto, dkk (2014: 3) PTK adalah suatu bentuk pencermatan terhadap kegiatan belajarberupa sebuah tindakan yang sengaja dimunculkan dan terjadi dalam sebuah kelas secarabersama. PTK ini harus menyangkut upaya guru dalam bentuk proses pembelajaran karena dimaksudkan untuk meningkatkan hasil belajar (Arikunto, 2014: 2).

Penelitian ini dilakukan dari bulan September sampai dengan bulan Desember 2020di kelas XII IPS 1 SMAN 1 Garut melalui daring. Peneliti memilih kelas XII IPS 1 karena berdasarkan hasil ulangan harian KD menulis teks cerita sejarah, kelas ini memperoleh rata-rata nilai terendah dibandingkan kelas lain dengan jumlah siswa tidak tuntas terbanyakDalam proses tindakan, peneliti memerlukan pihak lain yang membantu untuk melakukan pengamatan. Oleh karena itu, penelitian tindakan kelas ini akan dilakukan secara kolaboratif, yaitu dengan melakukan kerjasama dengan rekan sejawat. Hal ini sejalan dengan pendapat Arikunto (2014:63) bahwa PTK kolaboratif adalah adanya kolaborasi (kerjasama) antara praktisi (guru, kepala sekolah, teman sejawat, siswa dan lain-lain) dan peneliti (dosen, widyaiswara) dalam pemahaman, kesepakatan tentang permasalahan, pengambilan keputusan yang akhirnya melahirkan kesamaan tindakan.

Dalam melaksanakan penelitian tindakan kelas ini. Desain penelitian yang digunakanberbentuk siklus model Kemmis dan McTaggrat. Secara garis besar empat tahapan yangdilalui adalah perencanaan, pelaksanaan tindakan, observasi, dan refleksi (Arikunto, dkk,2014:16). Hal ini sejalan dengan apa yang dilakukan Attamimi (2020) 
bahwa tindakan dalam siklus penelitiannya memuat planning, implementing, observing, and reflecting. Untuk lebih jelasnya, rencana tindakan pada tiap siklus adalah sebagai berikut.

\section{Siklus Pertama}

Perencanaan pada siklus I dilakukan berdasarkan penyebab masalah pada pembelajaran prasiklus guru. Kegiatan pada tahap perencanaan yaitu: 1) menyiapkan skenario pembelajaran yang berisi tentang kegiatan-kegiatan yang akan dilakukan meliputi kegiatan pendahuluan, inti dan penutup, 2) menyiapkan instrumen pengambilan data yang berupa lembar observasi dan lembar pedoman penilaian, dan 3) mempersiapkansiswa untuk mengikuti pembelajaran siklus pertama.

Tindakan pada siklus ini, terdapat beberapa tahapan sesuai dengan model pembelajaran yang dipilih yakni model discovery learning. Pada tahap pemberian rangsangan (stimulation), siswa membaca dan mengamati teks cerita sejarah "Mangir" dan artikel "Mengenang Sosok Kartini". Selanjutnya, siswa mengidentifikasi fakta-faktasejarah dan unsur imajinasi yang terdapat dalam teks-teks tersebut pada tahap identifikasi masalah (problem identification). Pada tahap pengumpulan data (data collection), siswa mencari referensi lain mengenai fakta tentang Kartini sebagai bahan teks cerita sejarah yang akan disusun. Pada tahap pemrosesan data (data processing), siswa menyusun teks cerita sejarah berdasarkan fakta yang telah ditemukan dan garis besar ide pengembanganimajinatif. Selanjutnya, pada tahap pembuktian (verification) adalah saling menganalisishasil teks cerita yang disusun oleh teman lain berdasarkan teori kriteria teks cerita sejarah yang telah dipelajari sebelumnya. Pada tahap akhir, yakni menarik kesimpulan (generalization), siswa menyimpulkan hasil analisis teks cerita sejarah kelompok lain dan meyampaikannya dalam diskusi kelas untuk mendapatkan masukan terhadap hasil teks cerita sejarah dan analisis yang telah disampaikan.

Observasi pada siklus I dilakukan selama tindakan berlangsung. Instrumen yang digunakan adalah (1) lembar observasi yang mendeskripsikan penampilan perilaku siswa, reaksi, penerapan strategi dan suasana berlangsungnya kegiatan belajar mengajar, dan (2) peran guru dalam menerapkan model pembelajaran discovery learning untuk meningkatkan keterampilan menulis teks cerita sejarah siswa. Setelah tindakan dilakukan, diamati, dikoreksi dan diberi waktu pengulangan, kemudian dinilai atau dievaluasi dengan menggunakan instrumen yang telah dipersiapkan.

Kegiatan pada siklus I diakhiri oleh refleksi, pada tahap ini, guru bersama kolaborator menganalisis hasil tes dan hasil observasi pada siklus I. Apabila terdapat aspek yang yang belum mencapai indikator keberhasilan dapat ditindaklanjuti pada siklus berikutnya. Di sisi lain, hal yang sudah baik pada siklus 1 bisa dipertahankan atau bahkan ditingkatkan.

\section{Siklus Kedua}

Perencanaan pada siklus II dilakukan berdasarkan hasil refleksi pada pelaksanaan siklus I. Kegiatan tersebut adalah 1) menyiapkan rencana pembelajaran yang akan dilakukan meliputi kegiatan pendahuluan, inti dan penutup, 2) menyiapkanmedia film untuk proses pembelajaran, 3) menyiapkan instrumen pengambilan data yang berupa lembar observasi dan lembar pedoman penilaian, dan 4) mempersiapkan siswa untuk mengikuti pembelajaran siklus kedua. 
Tindakan pada siklus II merupakan perbaikan terhadap kekurangan-kekurangan yang terdapat pada siklus I dengan langkah pembelajaran yang hampir sama dengan siklus I. Perbaikan yang dilakukan diantaranya adalah penambahan media film. Observasi difokuskan pada faktor yang menjadi kelemahan penulisan teks cerita sejarah siswa berdasarkan hasil refleksi siklus 1. Hasil observasi ini dapat menjadi dasar kesimpulan sejauh mana tingkat keberhasilan proses pembelajaran teks cerita sejarah menggunakan model discovery learning dengan penambahan media film.

Refleksi siklus II dilakukan untuk mengetahui keberhasilan pelaksanaan perbaikan tindakan siklus I. Refleksi dilakukan dengan cara menganalisis hasil tes dan hasil observasi, yang dilakukan pada siklus II. Guru berdiskusi dengan kolaborator untukmenentukan kekurangan dan kelebihan yang dicapai dalam siklus II. Jika hasil pembelajaran belum mencapai indikator keberhasilan, perlu dilakukan siklus selanjutnya dengan perbaikan pada kekurangan-kekurangan yang terjadi dalam siklus II. Akan tetapi, jika hasil pembelajaran sudah memenuhi indikator keberhasilan, penelitian selesai pada siklus II.

\section{Subjek dan Objek Penelitian}

Subjek penelitian ini adalah siswa kelas XII IPS 1 SMAN 1 Garut yang berjumlah 36 siswa. Terdiri dari siswa laki-laki sebanyak 14 orang dan siswa perempuan sebanyak 22 orang. Sementara itu, objek pada penelitian ini yaitu kemampuan menulis teks cerita sejarah dengan indikator aspek kelengkapan isi, keruntutan struktur dan ketepatan unsur kebahasaan, ketepatan susunan kalimat, dan ketepatan ejaan.

\section{Teknik Pengumpulan Data}

Pengumpulan data dalam penelitian ini menggunakan teknik observasi dan tes. Observasi dilakukan oleh guru bersama kolaborator selama proses pembelajaran berlangsung. Data yang diperoleh dari hasil observasi ini berupa catatan hasil pengamatan kegiatan guru dan siswa selama pembelajaran baik ketika proses menyimak penjelasan guru maupun ketika proses diskusi kelompok dalam room khusus atau diskusi kelas di room utama. Data tersebut digunakan sebagai gambaran peningkatan proses pembelajaran yang terjadi pada siklus I dan II. Observasi dilakukan dengan cara:

1) Menyiapkan lembar observasi yang berisi aspek-aspek mengenai perilaku peserta didik selama pembelajaran berlangsung;

2) Melaksanakan pengamatan selama proses penelitian berlangsung yaitu dari awal hingga berakhirnya proses pembelajaran;

3) Mencatat hasil observasi dengan mengisi lembar observasi yang telah dipersiapkan.

Teknik tes digunakan untuk memperoleh hasil belajar siswa berupa nilai sebagai bahan penarikan kesimpulan tingkat keberhasilan belajar dalam mencapai tujuan pembelajaran. Tes dalam penelitian ini dilakukan sebanyak dua kali, yaitu saat siklus I dan siklus II. Bentuk tes dan kriteria penilaian yang digunakan pada siklus I dan siklus II sama yaitu berbentuk tes tertulis. Hasil tes pada siklus I dianalisis untuk mengetahui kesulitan atau kelemahan yang dialami peserta didik. Kelemahankelemahan tersebut selanjutnya diperbaiki pada pelaksanan tes siklus II. Dengan demikian, peneliti akan mudah mengetahui peningkatan yang terjadi dalam keterampilan peserta didik menyusun teks cerita sejarah pada siklus I dan siklus II. 


\section{Teknik Pengumpulan Data}

Berdasarkan teknik pengumpulan data yang digunakan, alat pengumpulan data dalam penelitian ini berupa lembar observasi dan lembar penilaian menulis teks cerita sejarah. Lembar observasi digunakan untuk memperoleh data tentang situasi ketika proses pembelajaran berlangsung. Aspek-aspek yang diamati dalam proses menyusun teks cerita sejarah menggunakan model discovery learning dan media film, antara lain: 1) antusiasme peserta didik untuk memahami pembelajaran menyusun teks cerita sejarah secara tertulis, 2) kondusif atau tidaknya proses diskusi peserta didik dalam pembelajaran menyusun teks cerita sejarah secara tertulis, 3) reflektif atau tidaknya proses akhir pembelajaran sehingga peserta didik dapat menyadari kekurangan dan mengetahui apa yang akan dilakukan setelah proses pembelajaran.

Sementara itu, lembar penilaian menulis teks cerita sejarah digunakan untuk mendapatkan data keterampilan menyusun teks cerita sejarah peserta didik setelah menggunakan model discovery learning pada siklus I dan dibantu media film pada siklus II. Penilaian yang digunakan dalam penelitian ini berupa tes tertulis esai. Hasil tes tersebut akan dijadikan tolok ukur keberhasilan peningkatan keterampilan menyusun teks cerita sejarah. Adapun pedoman penilaian keterampilan menyusun teks cerita sejarah dapat dilihat pada lampiran.

\section{Teknik Analisis Data}

Dalam penelitian ini, sumber data diperoleh dari data primer yang bersumber dari hasil pengamatan selama pembelajaran menulis teks cerita sejarah menggunakan model discovery learning, mulai dari awal pembelajaran, proses diskusi baik diskusi kelompik di room khusus maupun diskusi kelas di room utama, sampai akhir pembelajaran. Selainitu, data diperoleh juga dari hasil tes menulis teks cerita sejarah siswa untuk mengukur ketercapaian proses belajar sekaligus untuk mengukur indikator keberhasilan penelitian. Selanjutnya, analisis data dilakukan secara interaktif. Menurut Milles dan Huberman (dalam Sugiyono, 2008:246) aktivitas dalam analisis data secara interaktif yaitu reduksi data (data reduction), penyajian data (data display), dan penarikan kesimpulan/verifikasi data (conclusion drawing/verification).

Untuk mengetahui peningkatan hasil belajar siswa dengan menerapkan model pembelajaran discovery learning dengan media film, data yang diperlukan berupa data hasil belajar yang diperoleh dari hasil belajar/nilai tes. Seorang siswa disebut tuntas belajar jika telah mencapai skor 80 persen ke atas. Untuk menghitung hasil belajar, dilakukan dengan membandingkan jumlah nilai yang diperoleh siswa dengan jumlah skor maksimum kemudian dikalikan $100 \%$ atau digunakan rumus Percentages Correction sebagai berikut (Purwanto, 2006:11).

$$
\mathrm{S}=\frac{R}{N} \times 100
$$

Keterangan:

S: Nilai yang dicari/diharapkan

$\mathrm{R}$ : jumlah skor dari item/soal yang dijawab benar

$\mathrm{N}$ : skor maksimal ideal dari tes tersebut. 
Adapun teknik analisis data yang digunakan untuk mengetahui peningkatan hasil belajar siswa pada penelitian ini yakni dengan membandingkan persentase ketuntasan belajar dalam penerapan model pembelajaran discovery learning pada siklus I danditambah media film pada siklus II. Sementara itu, persentase ketuntasan belajar dihitung dengan cara membandingkan jumlah siswa yang tuntas belajar dengan jumlah siswa secara keseluruhan (siswa maksimal) kemudian dikalikan $100 \%$.

$$
\text { Presentase Ketuntasan: } \mathrm{P}=\frac{\text { jumlah siswa yang tuntas belajar }}{\text { jumlah siswa maksimal }} \times 100 \%
$$

\section{Indikator Keberhasilan}

Indikator keberhasilan dalam peningkatan keterampilan menulis teks cerita sejarah menggunakan model pembelajaran discovery learning melalui media film adalah sebagaiberikut.

Tabel 1. Indikator Keberhasilan

\begin{tabular}{lc}
\hline Indikator & Hasil Akhir (Min.) \\
\hline Rata-rata Nilai & $\mathbf{8 0}$ \\
\hline Ketuntasan & $\mathbf{9 0}$ \\
& $\%$ \\
\hline
\end{tabular}

\section{HASIL PENELITIAN}

\section{Deskripsi Hasil Siklus I}

Pembelajaran yang dilakukan pada kondisi awal adalah dengan mengikuti tuntunan buku paket yakni (1) siswa mendata peristiwa sejarah dari berbagai sumber, (2) siswa memilih salah satu peristiwa sejarah yang paling menarik, (3) siswa membuat bagianbagian peristiwa faktual, sisi lain kehidupan tokoh, serta imajinasi ke dalam kerangka cerita, (4) siswa membuat rangkaian peristiwa faktual, dan (5) siswa menyusun cerita sejarah berdasarkan daya khayal. Berdasarkan hasil penilaian teks cerita sejarah yang dilakukan pada tanggal 8 September 2020, dapat diketahui bahwa dari 36 siswa baru 8 siswa $(22,2 \%)$ yang mencapai nilai 80 , sedangkan 28 siswa $(77,8 \%)$ nilainya masih di bawah 80 dengan rata-rata kelas yang diperoleh 70,4 atau dapat dilihat seperti pada tabelberikut.

Tabel 2. Pencapaian Nilai Menulis Teks Cerita Sejarah Kelas XII IPS 1 pada Kondisi Awal

\begin{tabular}{|c|c|c|c|c|}
\hline \multicolumn{3}{|c|}{ Pencapaian Nilai (Min. 80) } & \multirow[b]{2}{*}{ Presentase } & \multirow{2}{*}{$\begin{array}{c}\text { Rata-rata } \\
\text { Kelas }\end{array}$} \\
\hline Tuntas & Presentase & Belum Tuntas & & \\
\hline 8 siswa & $22,2 \%$ & 28 siswa & 77,8 & 70,4 \\
\hline
\end{tabular}

Dilihat dari hasil teks cerita sejarah siswa, unsur kesalahan terbanyak terdapat pada pengembangan isi yang belum tepat, pengembangan topik yang kurang sesuai, dan pengungkapan gagasan pada struktur teks yang kurang jelas. Hal ini menyebabkan hasil teks cerita sejarah siswa cenderung terpaku pada fakta-fakta sejarah yang seharusnya hanya menjadi dasar pengembangan teks cerita sejarah saja. Daya imajinasi siswa yang seharusnya mendominasi teks cerita sejarah yang ditulis, belum tergali dengan baik. Selain itu, siswa juga masih kesulitan untuk menyusun kalimat yang efektif danmenggunakan ejaan dengan benar.

\section{Deskripsi Hasil Siklus 1}




\section{Perencanaan}

Sebelum melaksanakan tindakan siklus I, hal-hal yang dilakukan peneliti bersama kolaborator adalah 1) menetapkan waktu pelaksanaan penelitian tindakan kelas siklus I yang membutuhkan 2 kali pertemuan yakni pada hari Selasa tanggal 10 dan 17 November 2020, 2) menyusun rancana pelaksanaan pembelajaran (RPP) yang akan digunakan dalammeningkatkan keterampilan menulis teks cerita sejarah menggunakan model pembelajaran discovery learning, 3) mempersiapkan lembar soal, dan 4) mempersiapkaninstrumen pengambilan data yang berupa lembar observasi dan lembar pedoman penilaian.

\section{Pelaksanaan}

Pelaksanaan kegiatan pembelajaran menggunakan aplikasi zoom. Pembelajaran dimulai dengan mengecek kehadiran siswa, mengecek power point, dan mengecek bahan ajar penunjang yang terdapat di google. Setelah mengucapkan salam, guru memberikan apersepsi tentang film dan novel fiksi yang bertema sejarah.

Pada kegiatan inti, pembelajaran dilakukan dengan menggunakan model discovery learning. Ada beberapa tahapan yang dilakukan yakni tahap pemberian rangsangan (stimulation), tahap identifikasi masalah (problem identification), tahap pengumpulan data (data collection), tahap pemrosessan data (data processing), tahap pemrosessan data (data processing), tahap pembuktian (verification), tahap menarik kesimpulan (generalization).

Pada tahap pemberian rangsangan, guru membagi siswa menjadi 7 kelompok yang terdiri atas lima sampai enam siswa per kelompok. Selanjutnya guru meminta siswa dalam kelompoknya membaca dan mengamati teks cerita sejarah "Mangir" dan artikel "Mengenang Sosok Kartini".

Pada tahap identifikasi masalah (problem identification) guru meminta siswa mengidentifikasi fakta-fakta sejarah dan unsur imajinasi yang terdapat dalam teks cerita sejarah "Mangir" dan fakta-fakta sejarah pada artikel "Mengenang Sosok Kartini". Setiapkelompok berdiskusi dan bertanya jawab hasil mengidentifikasi faktafakta sejarah dan unsur imajinasi yang terdapat dalam teks cerita sejarah "Mangir". Guru membimbing siswa untuk mengelompokkan hal-hal imajinatif dan fakta, baik tokoh maupun peristiwa,yang terdapat dalam teks cerita sejarah "Mangir".

Pada tahap pengumpulan data (data collection), guru meminta siswa untuk mengamati artikel "Mengenang Sosok Kartini". Selanjutnya, guru meminta siswa untuk menentukan tema teks cerita sejarah "Kartini" dan mencari referensi lain mengenai Kartini. Setelah mendapatkan fakta-fakta tentang kartini, guru meminta siswa berdiskusi dalam kelompoknya untuk saling berbagi ide pengembangan teks cerita sejarah sesuai dengan imajinasi masing-masing anggota kelompok sebagai bahan teks cerita sejarah yang akan disusun.

Pada tahap pemrosesan data (data processing) guru meminta siswa untuk menyusun teks cerita sejarah berdasarkan fakta dan garis besar ide pengembangan imajinatif yang telah disepakati bersama.

Pada tahap pembuktian (verification), guru menentukan kelompok-kelompok yang 
akan saling menganalisis teks cerita sejarah siswa. Guru meminta siswa untuk saling mengirimkan teks cerita sejarah yang telah disusunnya ke kelompok lain melalui ruang chat. Guru meminta siswa secara berkelompok untuk memasuki room breakout untuk berdiskusi. Siswa saling menganalisis hasil pekerjaan teman kelompok lain berdasarkan teori kriteria teks cerita sejarah yang telah dipelajari sebelumnya di room kelompok masing-masing selama 20 menit.

Pada tahap menarik kesimpulan (generalization), siswa menyimpulkan hasil analisisteks cerita sejarah kelompok lain. Lalu, guru meminta siswa untuk kembali ke room utama. Selanjutnya, siswa meyampaikan hasil teks cerita sejarah kelompok lain beserta analisisnya. Kelompok yang lain bersama guru menyimak dengan baik dan memberikan masukan terhadap hasil teks cerita sejarah dan analisis yang telah disampaikan. Pada kegiatan akhir, siswa dibimbing guru untuk menyimpulkan materi yang telah dipelajari. Guru menutup pembelajaran dan mengucapkan salam. Siswa merespons salamguru.

\section{Observasi}

Tahap observasi dilaksanakan bersamaan dengan tahap tindakan. Kegiatan observasi ini menggunakan lembar observasi yang telah disiapkan. Pelaksanaan pengamatan dilakukan oleh kolaborator. Sementara itu, penilaian hasil belajar menggunakan pedomanpenilaian dan dilakukan oleh guru.

Berdasarkan hasil observasi pada kegiatan pembelajaran dapat diketahui bahwa proses pembelajaran dititikberatkan pada penggunaan model pembelajaran discovery learning. Pada pertemuan pertama siklus I, siswa merespons baik dalam menerima materiyang diberikan oleh guru. Hal ini ditunjukan dengan keterlibatan siswa dalam berbagai tahapan kegiatan pembelajaran. Aktivitas siswa yang lain juga dapat dilihat dari bagaimana siswa berusaha untuk dapat mengidentifikasi unsur imajinatif dan fakta yang terdapat pada contoh teks cerita sejarah. Selain itu, siswa juga terlihat antusias ketika saling berbagi ide untuk menentukan alur cerita teks cerita sejarah yang akan disusun. Walaupun ketika berdiskusi di room masing-masing kelompok, masih terlihat sebagian siswa yang kurang aktif dan menyerahkan keputusan kepada temantemannya. Begitu juga ketika siswa berdiskusi pada room utama. Hanya sebagian kecil siswa yang memberikan masukan dan pertanyaan terhadap kelompok yang sedang memaparkan hasilanalisis teks sejarah. Siswa yang memaparkan hasil analisisnya pun masih ada yang terlihat tidak yakin dengan hasil analisis kelompoknya.

Sementara itu, jika ditinjau dari prosedur model discovery learning, aktivitas guru dalam pertemuan ini dapat dikatakan sangat baik. Guru melakukan tahapan secara sistematis, runtut, jelas dan tepat dalam menggunakan model pembelajaran tersebut. Guruberusaha memancing siswa yang kurang aktif untuk bisa menyampaikan pendapat ataupun pertanyaan. Namun, sebagian siswa masih belum merespons dengan baik.

Pada pertemuan kedua siklus I, aktivitas guru dan siswa masih sama baiknya denganpertemuan pertama. Antusiasme siswa ketika berdiskusi mengenai analisis hasil teks cerita sejarah siswa lain dalam room kelompoknya sudah cukup baik walaupun siswa yang pada pertemuan pertama kurang aktif, masih tetap kurang aktif. Sebagian siswa hanya menyimak tanpa memberikan kontribusi pendapat untuk kelompoknya.

Ketika proses pemaparan hasil diskusi analisis teks cerita sejarah kelompok lain 
pada room utama, sebagian siswa sudah cukup aktif untuk memberikan masukan dan pertanyaan. Sementara itu, siswa yang mendapat kesempatan memaparkan hasil analisisnya, sebagian besar sudah bisa memaparkan dengan baik. Meskipun demikian masih ada siswa yang kelihatan ragu-ragu dan kurang yakin dengan apa yang dipaparkannya.

Secara umum, dari pertemuan pertama dan kedua, siswa yang aktif masih belum banyak. Sebagian besar siswa masih pasif hanya menyimak pemaparan guru dan siswa lain. Suasana belajar tampak lebih kondusif. Walaupun ketika siswa memasuki room khusus yang disediakan untuk melakukan diskusi, masih ada siswa yang terlihat kurang fokus, terutama sebelum guru memasuki room mereka.

Sementara itu, berdasarkan hasil penilaian belajar siswa dapat diketahui bahwa hasil belajar menulis teks cerita sejarah pada siklus I siswa kelas XII IPS 1 adalah sebagai berikut.

Tabel 3. Pencapaian Nilai Menulis Teks Cerita Sejarah Kelas XII IPS 1 Siklus I

\begin{tabular}{|c|c|c|c|c|}
\hline \multirow[b]{2}{*}{ Tuntas } & \multicolumn{2}{|c|}{ Pencapaian Nilai (Min. 80) } & \multirow[b]{2}{*}{ Presentase } & \multirow{2}{*}{$\begin{array}{c}\text { Rata-rata } \\
\text { Kelas }\end{array}$} \\
\hline & Presentase & Belum Tuntas & & \\
\hline 24 siswa & $66,67 \%$ & 12 siswa & $33.33 \%$ & 78,30 \\
\hline
\end{tabular}

Dari tabel di atas dapat terlihat bahwa siswa yang sudah mencapai nilai minimal 80 adalah 24 persen atau sebanyak 66, 67 persen. Terjadi peningkatan sebanyak 16 siswa atau sebesar 44, 45 persen. Sementara itu, siswa yang belum mencapai KKM sebanyak 12 orang atau sebanyak 33,33 persen. Adapun rata-rata kelas adalah 78,30. Artinya, terjadi peningkatan rata-rata kelas dibandingkan dengan kondisi awal sebanyak 7,9.

Berdasarkan hasil penilaian teks cerita sejarah siswa yang telah disusun, sebagian besar siswa sudah dapat mengembangkan isi teks dengan baik baik, relevan dengan topikyang dibahas, dan memuat unsur kebahasaan yang lengkap. Namun, masih banyak siswayang kesulitan dalam menggunakan kalimat efektif, pengungkapan gagasan pada setiap struktur masih belum jelas dan tidak berkaitan, alur cerita yang masih terkesan loncat- loncat, dan penggunaan EYD yang masih belum konsisten.

\section{Refleksi}

Tahap keempat dalam penelitian tindakan kelas adalah refleksi. Refleksi merupakan kegiatan untuk mengungkapkan kembali apa yang sudah dilakukan, menguraikan informasi, mengkaji secara mendalam kekurangan dan kelebihan tindakan tersebut. Hal ini dilakukan untuk mengetahui seberapa besar peningkatan keterampilan menulis teks cerita sejarah menggunakan model discovery learning. Berdasarkan hasil siklus 1, dapat disimpulkan bahwa keterampilan menulis teks cerita sejarah siswa kelas XII IPS 1 mengalami peningkatan dibandingkan dengan kondisi awal. Hal ini dapat dilihat dari nilai rata-rata kelas yang meningkat 7, 9 dari 70,4 menjadi 78, 3. Selain itu, persentase siswa yang memperoleh nilai minimal 80 juga mengalami kenaikan sebesar 44, 45 persen dari 22, 2 persen pada kondisi awal menjadi 66, 67 persen pada siklus I. 
Hasil tersebut tentu saja belum mencapai indikator keberhasilan tindakan yang sudah ditetapkan sebelumnya yakni minimal $90 \%$ siswa mendapatkan nilai minimal 80. Meskipun sudah terjadi kenaikan, tetapi hasil tersebut belum optimal. Salah satu indikator yang menunjukan bahwa proses pembelajaran belum optimal yaitu hasil observasi menunjukan bahwa keaktifan siswa selama proses pembelajaran belum menyeluruh baikketika diskusi kelompok maupun ketika diskusi kelas.

Selain itu, hasil belajar siswa juga belum optimal. Sebagian siswa sudah dapat mengembangkan cerita sejarah dengan baik. Unsur imajinasi mulai mendominasi beberapa teks cerita sejarah yang disusun dengan penggunaan kalimat efektif dan EYD yang baik dan konsisten. Namun demikian, masih banyak siswa yang kurang bisa mengembangkan sisi imajinatif dalam teks cerita sejarah mereka. Porsi fakta sejarah masih lebih banyak dibanding sisi imajinatif. Beberapa siswa juga masih belum konsistendalan penggunaan kalimat yang efektif dan EYD yang tepat.

Oleh karena itu, diperlukan upaya perbaikan pembelajaran pada siklus II. Ada beberapa hal yang direfleksikan untuk diperbaiki pada tindakan siklus II, yaitu a) sebagian siswa masih kurang aktif dalam diskusi kelompok, b) sebagian siswa masih bersikap mengandalkan teman lain yang dianggap pintar untuk presentasi dan mengemukakan pendapat, c) sebagian besar siswa sudah dapat mengembangkan teks cerita sejarah berdasarkan imajinasi mereka tetapi beberapa siswa masih mengalami kesulitan sehingga teks cerita sejarah yang disusun masih didominasi oleh fakta-fakta sejarah, dan d) beberapa siswa masih ragu-ragu atau kurang percaya diri saat diminta untuk mengemukakan pendapat dan memberi masukan ketika teman lain memaparkan hasil analisis teks cerita sejarah kelompok lain.

Meskipun demikian, secara keseluruhan pelaksanaan proses kegiatan belajar mengajar menulis teks cerita sejarah menggunakan model discovery learning ini sudah berjalan dengan lancar. Di sisi lain, beberapa hal positif juga terlihat dalam proses tindakan siklus 1 . Beberapa hal positif itu antara lain, a) siswa bisa fokus mengikuti proses pembelajaran terutama dalam diskusi kelompok dalam room khusus, b) siswa mulai mendapat gambaran tentang teks cerita sejarah yang benar ketika proses saling menganalisis hasil pekerjaan teman lain, dan c) siswa mendapat penguatan tentang halhal yang sudah tepat atau belum tepat dalam pengembangan teks cerita sejarah ketika proses pemaparan per kelompok dalam room utama.

\section{Deskripsi Hasil Siklus II}

Hasil tindakan pada siklus I masih belum maksimal sehingga dilakukan upaya perbaikan melalui siklus II. Berikut rincian kegiatan yang dilakukan pada siklus II.

\section{Perencanaan}

Perencanaan pada siklus II ini dilakukan untuk menyamakan persepsi dalam upaya mengatasi permasalahan yang terjadi pada siklus I. Guru bersama kolaborator merancangpembelajaran menulis teks cerita sejarah menggunakan model pembelajaran discovery learning yang akan dilaksanakan pada siklus II. Hasil dari perencanaan siklus II adalah ;

1) Peneliti dan guru menetapkan waktu pelaksanaan penelitian tindakan kelas pada hari Selasa tanggal 24 November dan 8 Desember 2020 sesuai dengan jadwal pelajaran Bahasa Indonesia di kelas XII IPS 1;

2) Menyusun Rancana Pelaksanaan Pembelajaran (RPP) yang akan digunakan dalam 
meningkatkan keterampilan menulis teks cerita sejarah menggunakan model pembelajaran discovery learning dengan penambahan mediafilm;

3) Guru menyiapkan media film yang akan digunakan, yakni film "Surat Cinta untuk Kartini";

4) Menyiapkan instrumen pengambilan data yang berupa lembar observasi dan lembar pedoman penilaian.

\section{Pelaksanaan}

Tahap pelaksanaan tindakan siklus II dilakukan berdasarkan perencanaan yang telah disepakati bersama kolaborator. Pembelajaran berlangsung dari pukul 07.00 sampai dengan 08.40 melalui aplikasi zoom. Pembelajaran dimulai dengan mengecek kehadiran siswa, power point, dan media film yang akan digunakan. Setelah guru mengucapkan salam, siswa memimpin doa, dan dilanjutkan dengan apersepsi. Pada kegiatan apersepsi, guru memancing pertanyaan dengan menanyakan tentang perjalanan cinta Kartini. Terakhir, guru menginformasikan tujuan dan langkah-langkah pembelajaran model discovery learning melalui media film yang akan dilaksanakan pada hari itu.

Seperti pada siklus I, pembelajaran pada siklus II juga melalui beberapa tahap sesuaidengan model yang dipilih yakni model pembelajaran discovery learning. Pada tahap pemberian rangsangan (stimulation), guru membagi siswa menjadi 7 kelompok yang terdiri atas lima sampai enam siswa per kelompok. Kelompok yang dibentuk berbeda dengan kelompok pada siklus I. Guru meminta siswa dalam kelompoknya membaca danmengamati kembali teks cerita sejarah "Mangir". Guru dan siswa saling bertanya jawab dan mengulas fakta sejarah dan unsur imajinasi yang terdapat pada teks mangir berdasarkan hasil analisi pada siklus I. Selanjutnya, guru meminta siswa untuk menyimak pemutaran film "Surat Cinta untuk Kartini" selama 10 menit pertama. Setelah 10 menit, film dihentikan.

Pada tahap identifikasi masalah (problem identification), guru membimbing siswa mengidentifikasi fakta-fakta sejarah dan unsur imajinasi yang terdapat dalam 10 menit pertama film "Surat Cinta untuk Kartini”. Selanjutnya guru meminta siswa untuk masukke dalam room khusus kelompok.

Pada tahap pengumpulan data (data collection), guru meminta siswa untuk mengembangkan teks cerita sejarah berdasarkan 10 menit pertama film yang telah ditonton dengan cara menentukan alur sendiri secara bebas sesuai dengan imajinasi masing-masing secara berkelompok. Siswa berdiskusi dan saling berbagi ide mengenai peristiwa dan perubahan nasib dari setiap tokoh dalam film tersebut tanpa mengubah fakta sejarah yang sudah ada. Pada tahap pemrosesan data (data processing), guru meminta siswa untuk menyusun teks cerita sejarah berdasarkan fakta dan garis besar ide pengembangan imajinatif yang telah disepakati bersama.

Pada tahap pembuktian (verification), guru menentukan kelompok-kelompok yang akan saling menganalisis teks cerita sejarah yang telah disusun siswa. Guru meminta siswa untuk saling mengirimkan teks cerita sejarah yang telah disusunnya ke kelompok lain. Guru meminta siswa secara berkelompok untuk memasuki room breakout untuk berdiskusi. Siswa saling menganalisis hasil pekerjaan teman kelompok lain berdasarkan teori kriteria teks cerita sejarah yang telah dipelajari sebelumnya di room kelompok masing-masing selama 20 menit. 
Pada tahap menarik kesimpulan (generalization), setelah siswa menyimpulkan hasil analisis teks cerita sejarah kelompok lain, guru meminta siswa untuk kembali ke room utama. Selanjutnya, siswa meyampaikan hasil teks cerita sejarah kelompok lain beserta hasil analisisnya. Kelompok yang lain bersama guru menyimak dengan baik dan memberikan masukan terhadap hasil teks cerita sejarah dan analisis yang telah disampaikan. Pada kegiatan akhir, siswa dibimbing guru untuk menyimpulkan materi pembelajaran. Guru menutup pembelajaran dan mengucapkan salam. Siswa meresponssalam guru.

\section{Observasi}

Tahap observasi pada siklus II ini sama dengan observasi pada tahap I. Berdasarkan hasil observasi kegiatan pembelajaran dapat diketahui bahwa proses pembelajaran dititikberatkan pada penggunaan model pembelajaran discovery learning dengan dibantumedia film "Surat Cinta untuk Kartini". Pada pertemuan pertama siklus II, terdapat peningkatan kedisiplinan siswa memasuki ruang pembelajaran zoom. Selain itu, seperti yang terjadi pada siklus I, siswa merespons baik dalam menerima materi yang diberikanoleh guru. Siswa terlibat dalam berbagai tahapan kegiatan pembelajaran dengan antusias. Tingkat partisipasi siswa ketika berdiskusi di room masing-masing sudah terlihat semakinbanyak yang aktif.

Sementara itu, aktivitas guru dalam pertemuan ini dapat dikatakan sangat baik. Dengan bantuan media film, guru terlihat lebih mudah menjelaskan bagaimana mengembangkan teks cerita sejarah. Selain guru melakukan tahapan secara sistematis, runtut, jelas dan tepat dalam menggunakan model pembelajaran tersebut, guru juga mampu memanfaatkan media film dengan efektif. Guru mampu memancing siswa yang sebelumnya kurang aktif menjadi lebih berani mengemukakan pendapat. Pada pertemuan kedua siklus II, aktivitas guru dan siswa masih sama baiknya dengan pertemuan pertama. Antusiasme siswa ketika berdiskusi mengenai analisis hasil teks cerita sejarah siswa laindalam room kelompoknya sudah cukup baik. Siswa yang sudah aktif sudah mulai meningkat, hanya 1 atau 2 siswa saja yang masih tetap kurang aktif.

Ketika proses pemaparan hasil diskusi analisis teks cerita sejarah kelompok lain pada room utama, sebagian siswa sudah cukup aktif untuk memberikan masukan dan pertanyaan. Guru mencoba memancing siswa yang belum aktif pada pertemuan pertamauntuk mengemukakan pendapatnya dengan pertanyaan-pertanyaan sederhana. Siswa yang belum pernah menyampaikan pendapat sebelumnya, sudah mulai berpendapatwalaupun masih dengan kalimat pendek dan langsung pada inti jawaban. Sementara itu, siswa yang mendapat kesempatan memaparkan hasil analisisnya, sebagian besar sudah bisa memaparkan dengan baik. Siswa terlihat lebih percaya diri dan yakin dengan apa yang dipaparkannya.

Secara umum dari pertemuan pertama dan kedua, siswa yang aktif sudah banyak. Sebagian besar siswa sudah mulai berpendapat walaupun tidak semua siswa mampu mengelaborasi pendapatnya. Suasana belajar secara keseluruhan tampak lebih kondusif, baik ketika siswa berdiskusi pada room khusus kelompok maupun pada room utama. 
Selanjutnya, dari Hasil Penilaian Belajar Siswa dapat diketahui hasil belajar menulisteks cerita sejarah pada siklus II siswa kelas XII IPS 1 adalah sebagai berikut.

Tabel 4. Pencapaian Nilai Menulis Teks Cerita Sejarah Kelas XII IPS 1

Siklus II

\begin{tabular}{|c|c|c|c|c|}
\hline \multicolumn{4}{|c|}{ Pencapaian Nilai (Min. 80) } & \multirow{2}{*}{$\begin{array}{c}\text { Rata-rata } \\
\text { Kelas }\end{array}$} \\
\hline Tuntas & Presentase & Belum Tuntas & Persentase & \\
\hline 33 siswa & $91,67 \%$ & 3 siswa & $8,33 \%$ & 88,92 \\
\hline
\end{tabular}

Dari tabel di atas dapat terlihat bahwa siswa yang sudah mencapai nilai minimal 80 adalah 33 siswa atau sebanyak 91, 67 persen. Terjadi peningkatan sebanyak 9 siswa atau sebesar 25 persen. Sementara itu, siswa yang belum mencapai KKM sebanyak 3 orang atau sebanyak 8,33 persen. Adapun rata-rata kelas adalah 88,92. Artinya, terjadi peningkatan rata-rata kelas dibandingkan dengan kondisi awal sebanyak 10, 62.

Dilihat dari hasil teks cerita sejarah siswa, sebagian besar siswa sudah dapat mengembangkan isi teks dengan baik baik dan relevan dengan topik yang dibahas, mengungkapkan gagasan dalam setiap struktur dengan jelas, menggunakan unsur kebahasaan dengan lengkap, dan menerapkan kalimat efektif serta EYD dengan cukup konsisten. Masih ada siswa yang masih kesulitan dalam menggunakan kalimat efektif, alur cerita yang masih terkesan loncat-loncat, dan penggunaan EYD yang masih belum konsisten, tetapi hanya beberapa orang saja.

\section{Refleksi}

Sesuai dengan hasil pada siklus 1, dapat diketahui bahwa keterampilan menulis teks cerita sejarah siswa kelas XII IPS 1 mengalami peningkatan dibandingkan dengan kondisiawal. Hal ini dapat dilihat dari nilai rata-rata kelas yang meningkat 10, 6 dari 78,3 menjadi 88, 9. Selain itu, persentase siswa yang memperoleh nilai minimal 80 juga mengalami kenaikan sebesar 25 persen dari 66,7 persen pada siklus 1 menjadi 91,7 persen pada siklus II.Hasil tersebut sudah memenuhi indikator keberhasilan yakni perolehan nilai rata-rata kelas minimal 80 dan jumlah siswa yang tuntas minimal 90 persen. Oleh karena itu, penelitian diakhiri pada siklus II.

\section{PEMBAHASAN}

Berdasarkan hasil observasi pada pelaksanaan penelitian siklus I dan II di kelas XII IPS 1 SMAN 1 Garut dapat diketahui bahwa aktivitas guru sudah sangat baik dalam proses pembelajaran baik pada kegiatan awal, inti, maupun akhir. Pada siklus I, guru dapat melaksanakan tahapan-tahapan proses pembelajaran menggunakan model discovery learning dengan baik. Proses pembagian kelompok juga berjalan dengan baik. Siswa memasuki room breakout dengan tertib. Hal ini menunjukkan bahwa persiapan guru untuk proses pembelajaran sudah cukup matang. Selain itu, aktivitas guru dalam pertemuan ini dapat dikatakan sangat baik. Guru melakukan tahapan secara sistematis, runtut, jelas dan tepat dalam menggunakan model pembelajaran discovery learning.

Antusiasme siswa dalam mengikuti pembelajaran juga cukup baik, walaupun siswa yang aktif berpendapat dalam diskusi kelompok maupun diskusi kelas masih sedikit. Siswa yang aktif hanya siswa yang sudah terbiasa berpendapat saja, belum menyeluruh. Beberapa siswa juga masih terlihat kurang percaya diri ketika memaparkan hasil analisisteks cerita sejarah kelompok lain. 
Sementara itu, pada siklus II, aktivitas guru dan siswa masih sama baiknya dengan siklus I. guru dapat memanfaatkan media film dengan efektif. Siswa terlihat lebih pahamuntuk menyusun teks cerita sejarah berdasarkan imajinasi masing-masing. Guru juga terlihat lebih mudah untuk memberikan gambaran pengembangan cerita. Penggunaan media film sebagai perangsang imajinasi siswa membuat siswa lebih fokus dan terarah. Suasana diskusi ketika saling berbagi imajinasi untuk merancang alur peristiwa maupun tokoh teks cerita sejarah menjadi semakin ramai.

Siswa yang sudah aktif di pertemuan pertama, masih terlihat aktif pada pertemuan kedua. Siswa yang pada pertemuan pertama kurang aktif, beberapa sudah menunjukkan bisa berpendapat dan menyumbang ide berdasarkan imajinasinya dan juga film yang telah ditonton. Guru mampu memancing siswa untuk berpendapat. Siswa yang belum pernah menyampaikan pendapat sebelumnya, sudah mulai berpendapat walaupun masih dengankalimat pendek dan langsung pada inti jawaban. Begitu juga dalam diskusi kelas pada room utama, pemaparan hasil analisis teks cerita sejarah berjalan hangat. Kelompok yangbertugas memaparkan mampu menerima masukan dan menjawab pertanyaan dengan lebih yakin.

Berdasarkan hasil observasi pada siklus I dan II, dapat diketahui bahwa terjadi peningkatan keaktifan siswa dalam berpendapat walaupun tidak semua siswa mampu mengelaborasi pendapatnya. Hal ini menunjukkan bahwa penambahan media film pada model pembelajaran discovery learning mampu memberikan gambaran dan menambah pemahaman siswa mengenai pengembangan ide penulisan teks cerita sejarah sehingga siswa lebih percaya diri dalam mengemukakan pendapat atau pertanyaan. Adapun mengenai perkembangan hasil belajar teks cerita sejarah siswa dari mulai kondisi awal, siklus 1, dan siklus II, dapat dilihat pada tabel berikut.

Tabel 5. Hasil Belajar Menulis Teks Sejarah Siswa Kelas XII IPS 1

\begin{tabular}{llccc}
\hline No & \multicolumn{1}{c}{ Indikator } & Kondisi awal & Siklus I & Siklus II \\
\hline $\mathbf{1}$ & Rata-rata Nilai & 70,4 & 78,3 & 88,9 \\
\hline $\mathbf{2}$ & Siswa Tuntas & $8(22,2 \%)$ & $24(66,7 \%)$ & $33(91,7 \%)$ \\
\hline $\mathbf{3}$ & Siswa Tidak Tuntas & $28(77,8 \%)$ & $12(33,3 \%)$ & $3(8,3 \%)$ \\
\hline
\end{tabular}

Dari tabel di atas, dapat diketahui bahwa terjadi peningkatan hasil belajar siswa dalam menulis puisi dari kondisi awal, tindakan siklus I, dan setelah tindakan siklus II.

Pertama, terjadi peningktan rata-rata nilai dari 70,4 pada kondisi awal, meningkat menjadi 78,3 setelah tindakan siklus I, dan meningkat lagi menjadi 88,9 pada siklus II. Hal ini berarti terjadi peningkatan sebesar 18, 5 poin. Kedua, terjadi peningktan jumlah siswa tuntas dari 8 siswa $(22,2 \%)$ pada kondisi awal, meningkat menjadi 24 siswa $(66,7 \%)$ setelah tindakan siklus I, dan meningkat lagi menjadi 33 siswa $(91,7 \%)$ pada siklus II. Hal ini berarti terjadi peningkatan sebanyak 25 siswa $(69,5 \%)$. Ketiga, terjadi penurunan jumlah siswa tidak tuntas dari 28 siswa (77,8\%)pada kondisi awal, menurun menjadi 12 siswa $(33,3 \%)$ setelah tindakan siklus I, dan menurun lagi menjadi 3 siswa $(8,3 \%)$ pada siklus II. Hal ini berarti terjadi penurunan sebanyak 25 siswa $(69,5 \%)$.

Oleh karena itu, berdasarkan pembahasan di atas, dapat diketahui bahwa penggunaan model pembelajaran discovery learning melalui media film dapat meningkatkan hasil belajar menulis teks cerita sejarah siswa Kelas XII IPS 1 SMAN 1 Garut. 


\section{KESIMPULAN}

Berdasarkan hasil penelitian dan pembahasan, dapat penulis simpulkan bahwa penggunaan model pembelajaran discovery learning melalui media film sangat efektif dalam meningkatkan hasil belajar menulis teks cerita sejarah siswa kelas XII IPS 1 SMAN 1 Garut. Hal ini dibuktikan dengan terpenuhinya indikator pertama yaitu nilai rata-rata di atas 80 , yakni menjadi 88,9 dengan peningkatan rata-rata nilai sebanyak 18,5 poin. Bukti selanjutnya adalah terpenuhinya indikator keberhasilan yang kedua yaitu jumlah siswa yang tuntas mencapai minimal 90 persen, yakni menjadi $91,7 \%$ dengan peningkatan sebanyak $69,5 \%$.

\section{Saran}

Berdasarkan hasil penelitian dan pembahasan, dapat dikemukakan saran sebagai berikut. Untuk guru Bahasa Indonesia, berdasarkan hasil penelitian yang sudah dilakukan, model pembelajaran discovery learning melalui media film dapat meningkatkan hasil belajar siswa dalam menulis teks cerita sejarah. Oleh karena itu, penulis menyarankan agar model pembelajaran discovery learning melalui media film inidapat digunakan sebagai alternatif dalam pembelajaran, baik dalam KD yang sama maupun dalam KD lainnya. Untuk peneliti berikutnya, disarankan agar meneliti lebih lanjut tentang penggunaan model pembelajaran discovery learning melalui media film untuk kompetensi dasar yang lainnya dalam mata pelajaran Bahasa Indonesia maupun dalam mata pelajaran lain sehingga hasil penelitian tersebut dapat dimanfaatkan lebih luaslagi.

\section{DAFTAR PUSTAKA}

Arikunto, Suharsimi dkk. (2014). Penelitian Tindakan Kelas. Jakarta: Bumi Aksara. Attamimi, dkk. (2020). Application of Habituation Method in Germas interventionsin:

The Pandemic Time COVID-19. SLOAP International Journal of Health \& Medical Sciences 3(2), 98 - 104. https://doi.org/10.31295/ijhms.v3n1.175

Hanafiah, N. (2012). Konsep Strategi Pembelajaran. Bandung: Rafika Aditama. Kemendikbud (2018). Bahasa Indonesia SMA/MA/SMK/MAK Kelas XII. Bandung: PT

Sarana Pancakarya Nusa.

Mulyasa, Dadang Iskandar dan Wiwik Dyah Aryani. (2016). Revolusi dan Inovasi Pembelajaran. Bandung: PT Remaja Rosdakarya.

Purwanto, Ngalim. (2006). Prinsip-prinsip dan Teknik Evaluasi Pengajaran, Bandung:Remaja Rosdakarya.

Sugiyono. (2008). Metodologi Penelitian Kuantitatif dan Kualitatif. Bandung: Alfabeta.Sumarno, Marselli. (1996). Dasar-Dasar Apresiasi Film. Jakarta: PT Gramedia.

Sutarno, NS. (2008). Menulis yang Efektif. Jakarta: CV Sagung Seto.

Syah, M. (2014). Psikologi Pendidikan dengan Pendekatan Baru. Bandung: RemajaRosdakarya. 